\title{
ANALISIS KESALAHAN SISWA SMP DALAM MENYELESAIKAN SOAL BERBENTUK HIGHER ORDER THINKING (HOT) PADA MATERI ALJABAR
}

Hendrika Bete, S.Pd.,M.Pd

bete.hendrika@yahoo.co.id

\begin{abstract}
ABSTRAK
Pendidikan dapat menjadi bekal bagi seseorang siswa untuk melakukan inovasi dan perbaikan dalam aspek - aspek kehidupannya yang mengarah pada peningkatan kualitas diri. Peran pendidikan tersebut sangatlah penting. Agar dapat tercapai peningkatan kualitas siswa yang lebih baik, salah satu upaya adalah melatih kemampuan tingkat berpikir secara khusus berpikir tingkat tinggi (Higher order thinking). Namun masih banyak terdapat kendala yakni masih banyak kesalahan - kesalahan yang dilakukan oleh siswa dengan jenis kesalahannya yakni kesalahan konsep, kesalahan prinsip dan kesalahan kecerobohan. Hasil penelitian ini bertujuan untuk menganalisis kesalahan siswa SMP dalam menyelesaikan soal berbentuk higher order thinking pada materi aljabar. Metode yang digunakan adalah tes dan wawancara terhadap 9 orang subjek penelitian dari 3 sekolah berdasarkan kemampuan siswa yakni kemampuan tinggi, kemampuan sedang dan rendah. Hasil penelitian menunjukkan bahwa terdapat perbedaan terhadap jenis kesalahan yang dilakukan oleh siswa yang memiliki kemampuan tinggi, kemampuan sedang dan kemampuan rendah.
\end{abstract}

Kata kunci: Analisis, kesalahan siswa, HOT

\begin{abstract}
Education can be a provision for a student to innovate and improve in aspects of his life that lead to improved self-quality. The role of education is very important. In order to achieve better quality improvement for students, one effort is to train the ability to think specifically in higher-order thinking (Higher order thinking). But there are still many obstacles, there are still many mistakes made by students with the types of errors, namely conceptual errors, principle errors and careless mistakes. The results of this study aim to analyze the errors of junior high school students in solving problems in the form of higher order thinking in algebraic material. The method used was a test and interview of 9 research subjects from 3 schools based on students' abilities, namely high ability, moderate ability and low ability. The results showed that there were differences in the types of errors made by students who had high abilities, moderate abilities and low abilities.
\end{abstract}

Keywords: Analysis, student error, HOT

\section{PENDAHULUAN}

Pendidikan merupakan suatu proses perubahan tingkah laku dan kemampuan seseorang menuju kearah yang lebih baik. Pendidikan dapat menjadi bekal bagi seseorang untuk melakukan inovasi dan perbaikan dalam aspek - aspek kehidupannya yang mengarah pada peningkatan kualitas diri. Peran pendidikan tersebut sangatlah penting. Berbagai masalah dalam pendidikan selalu menjadi perhatian bagi pemerintah di setiap negara, termasuk Indonesia. Pemerintah telah melakukan berbagai upaya dalam meningkatkan kualitas pendidikan yakni melakukan penyempurnaan dan perbaikan pada kurikulum sekolah, meningkatkan sarana dan prasarana pendidikan, mengeluarkan kebijakan untuk mengembangkan pendidikan nasional sesuai dengan tuntutan ilmu pengetahuan dan teknologi.

Matematika merupakan ilmu universal yang berguna bagi kehidupan manusia dan juga mendasari perkembangan teknologi modern, serta mempunyai peran penting dalam berbagai disiplin ilmu dan memajukan daya pikir manusia. Matematika merupakan bidang studi yang harus bisa dikuasai oleh siswa, karena merupakan sarana pemecahan masalah sehari - hari. Banyak orang berpikir bahwa matematika merupakan bidang studi yang paling sulit dan jarang diminati karena matematika merupakan suatu subjek ideal untuk mengembangkan pola pikir anak usia dini, usia pendidikan dasar, pendidikan lanjutan pertama, pendidikan menengah, maupun bagi mereka yang sudah di perguruan tinggi. 
Salah satu mata pelajaran di sekolah yang melatih siswa berpikir tingkat tinggi adalah mata pelajaran matematika. Krathwohl (dalam Aisyah 2019: 10) mengatakan bahwa indikator untuk mengukur kemampuan berpikir tinggi meliputi menganalisis, mengevaluasi dan mengkreasi. Seorang siswa dapat dikatakan memiliki kemampuan berpikir tinggi apabila dapat menganalisis, mengevaluasi,dan mengkreasikan soal dengan baik.

Namun masih terdapat banyak persoalan dalam proses belajar mengajar diantaranya adalah berdasarkan hasil penelitian, Mamoh (2015), data UN 2012/2013 siswa SMP secara nasional bahwa data nilai UN matematika siswa SMP dari provinsi NTT termasuk dalam kelompok terendah secara nasional. Sedangkan masalah lainnya adalah, pada saat guru memberikan penjelasan tentang suatu materi, tidak semua siswa dapat memahaminya dengan baik. Siswa yang belum memahami materi cenderung berdiam diri dan sukar bertanya kepada guru serta kurang memahami konsep dasar yang harus dikuasai. Hal ini mengakibatkan, saat guru memberikan soal latihan siswa banyak melakukan kesalahan. Dari kesalahan - kesalahan yang dilakukan siswa dalam menyelesaikan soal, sangatlah penting bagi seorang guru untuk meneliti dan mengidentifikasi jenis kesalahan serta faktor - faktor apa saja yang menyebabkan siswa melakukan kesalahan. Poerwadarminta (2003) menyatakan "salah berarti tidak sebagaimana mestinya, tidak betul, tidak benar, keliru sedangkan kesalahan berarti kekeliruan, penyimpanngan dari yang seharusnya kekhilafan, sesuatu yang salah, perbuatan salah".

Jenis - jenis kesalahan dalam penelitian ini dikelompokkan dalam tiga jenis kesalahan yakni kesalahan konsep, kesalahan prinsip dan kesalahan kecerobohan (Nurianti, E.dkk). Kesalahan konsep adalah kesalahan dalam memahami konsep matematika yang menjadi prasyarat maupun konsep yang telah diajarkan yaitu materi aljabar. Kesalahan prinsip adalah kekeliruan dalam mengaitkan beberapa fakta atau beberapa konsep dalam menyelesaikan soal bentuk aljabar. Kesalahan kecerobohan meliputi salah hitung dan salah tulis dalam menyelesaikan soal bentuk aljabar.

Berdasarkan latar belakang tersebut, peneliti ingin mengidentifikasi kesalahan - kesalahan yang dilakukan siswa dalam menyelesaikan soal berbentuk higher order thingking (HOT) pada materi aljabar.

\section{METODE}

Pendekatan yang digunakan adalah pendekatan kualitatif. Menurut Creswell (2012: 20) pendekatan kualitatif ditunjukkan untuk mengungkap suatu masalah dan mengembangkannya secara detail untuk memahami pusat fenomena yang muncul. Dilihat dari bagaimana penelitian dilakukan, maka penelitian ini termasuk dalam penelitian deskriptif. Penelitian deskriptif adalah penelitian yang diarahkan untuk mendeskripsikan gejala - gejala, fakta - fakta atau kejadian secara sistematis dan akurat mengenai sifat - sifat subjek penelitian (Riyanto, 2007: 107). Awalnya peneliti memberikan soal yang terdiri dari soal UN, OLIMPIADE dan PISA materi aljabar untuk 3 sekolah yang tersebar di kabupaten Timor Tengah Utara diantaranya SMP K St. Yoseph, SMP N 1 Biboki Selatan, SMP N Eban. Subjek dalam penelitian ini adalah 9 orang dengan 3 orang dari setiap sekolah yang melakukan kesalahan terbanyak berdasarkan kemampuan tinggi, kemampuan sedang dan kemampuan rendah.

\section{HASIL dan PEMBAHASAN}

Tes dan wawancara dilakukan terhadap 9 subjek penelitian. Berdasarkan masalah yang sudah dijelaskan pada bagian metode, berikut ini akan disajikan hasil penelitian terhadap 9 subjek penelitian yang melakukan kesalahan yakni; kesalahan konsep, kesalahan prinsip dan kesalahan kecerobohan.

\section{Hasil Penelitian Analisis Kesalahan Siswa SMP dalam Menyelesaikan Soal Pada Materi} Aljabar.

1. Analisis Kesalahan Siswa SMP N 1 Biboki Selatan dalam Menyelesaikan Soal pada Materi Aljabar

a. Analisis Kesalahan Siswa berkemampuan tinggi (S1) dalam menyelesaikan soal aljabar

Analisis kesalahan siswa berkemampuan tinggi (S1) dalam menyelesaikan soal pada materi aljabar diperoleh informasinya bahwa dari 6 soal uraian yang diberikan oleh peneliti, S1 


\section{Range: Jurnal Pendidikan Matematika Vol 1 No 1 Tahun 201C Hendrika Bete}

menyelesaikan 4 soal yakni soal 1,4,5 dan 6 . Untuk soal no 1, S1 melakukan kesalahan dalam menyelesaikan soal.

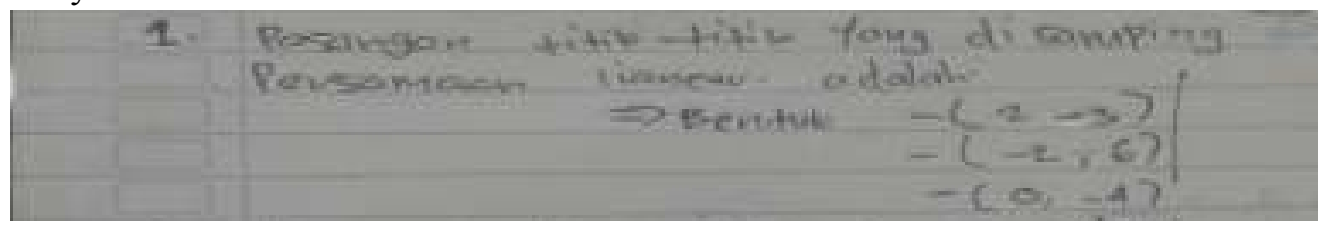

\section{Gambar 1}

Pada gambar 1, S1 melakukan kesalahan prinsip yakni S1 keliru dalam mengaitkan fakta pada soal dengan jawaban S1, soal yang diberikan adalah untuk menentukan persamaan linear, S1 menyelesaikan dengan memberikan bentuk titik sebagai jawaban. Selain itu juga, S1 melakukan kesalahan kecerobohan yakni, S1 salah menulis titik - titik yang diketahui dalam soal berbeda dengan yang diketahui pada jawaban. Selanjutnya adalah soal 4.

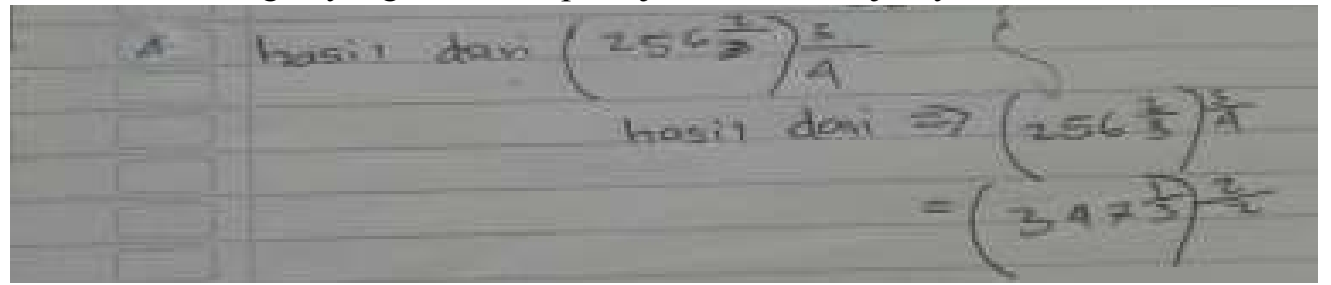

\section{Gambar 2}

S1 melakukan kesalahan konsep dalam menyelesaikan soal perpangkatan, dan juga kesalahan kecerobohan, karena S1 melakukan kesalahan dalam menghitung bilangan tersebut. Sedangkan soal no 5 adalah

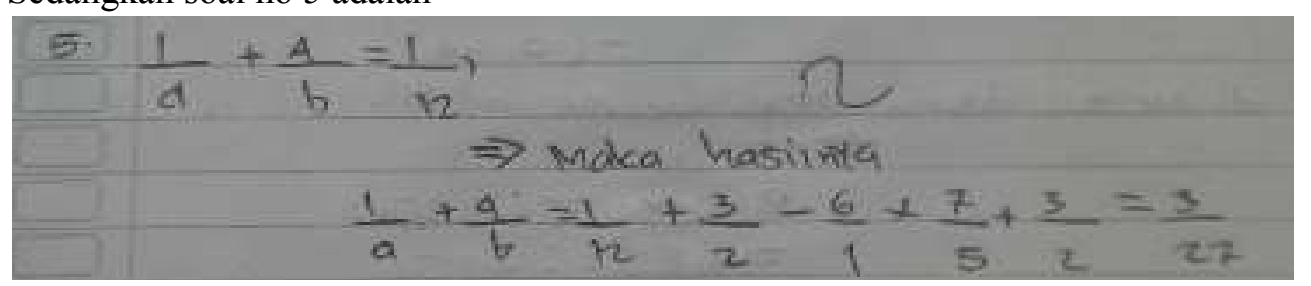

Gambar 3

S1 melakukan kesalahan kecerobohan yakni S1 salah dalam berhitung juga salah dalam menulis. Sedangkan pada soal no 6, S1 melakukan kesalahan konsep juga kesalahan prinsip.

b. Analisis Kesalahan Siswa berkemampuan sedang (S2) dalam menyelesaikan soal aljabar Analisis kesalahan siswa berkemampun sedang dalam menyelesaikan soal aljabar. ada 6 soal yang diberikan peneliti, S2 menyelesaikan 3 soal, yakni soal no 3, 4 dan 5. Soal no 3 yang diselesaikan oleh $\mathrm{S} 2$ adalah

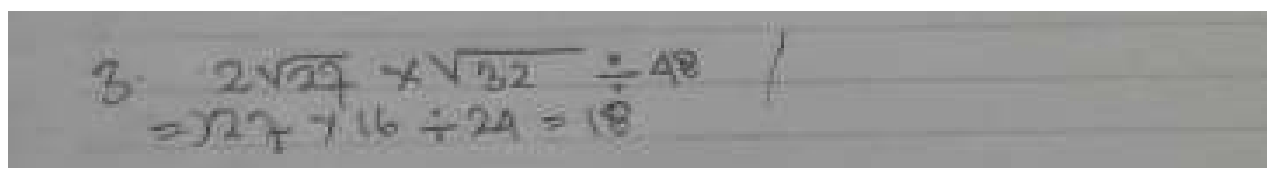

\section{Gambar 4}

Paada gambar 4, S2 melakukan kesalahan prinsip yakni S2 keliru dalam menghubungkan konsep penyelesaian bentuk akar, S2 menyelesaikan dengan menjumlahkan bilangan yang sama, seharusnya perkalian bilangan yang sama untuk bentuk akar. Sedangkan soal no 4,

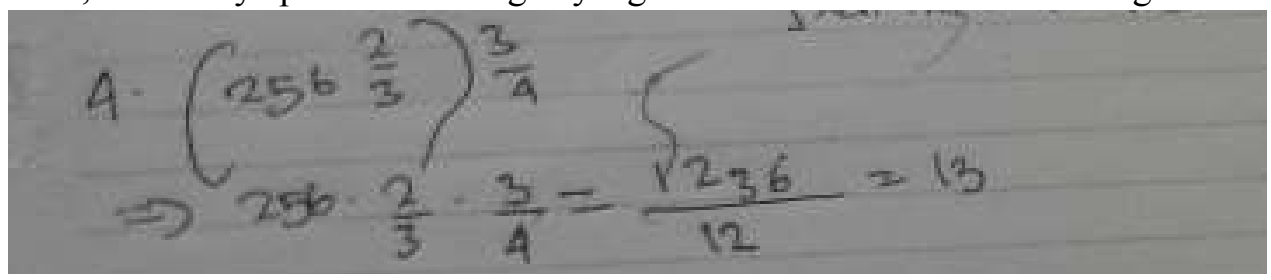

Gambar 5

S2 melakukan kesalahan konsep. S2 mengalikan bilangan pangkat dengan bilangan pokok. Soal no 5 


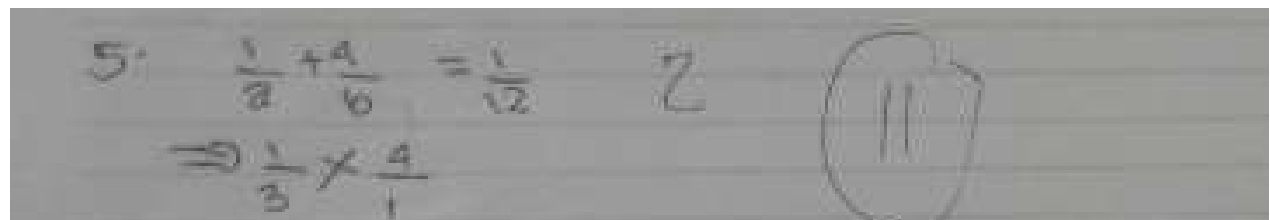

Gambar 6

S2 melakukan kesalahan konsep, kesalahan prinsip dan kesalahan kecerobohan.

c. Analisis Kesalahan Siswa berkemampuan rendah (S3) dalam menyelesaikan soal aljabar

S3 menyelesaikan 1 soal dari 6 soal yang diberikan peneliti, S3 melakukan kesalahan konsep, juga kesalahan kecorobohan.

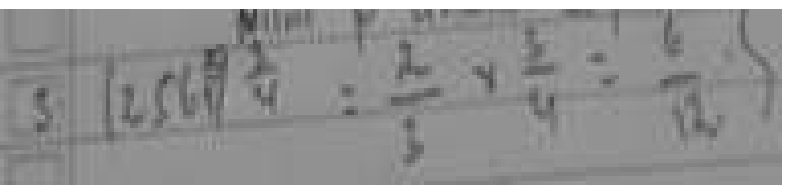

Gambar 7

\section{Analisis Kesalahan Siswa SMP K St. Yoseph dalam Menyelesaikan Soal pada Materi} Aljabar

a. Analisis kesalahan siswa berkemampuan tinggi (S1) dalam menyelesaikan soal HOT pada materi aljabar

S1 menyelesaikan 4 soal dari 6 soal yang diberikan oleh peneliti. Dari 6 soal yang diberikan masih terdapat kesalahan - kesalahan yang dilakukan oleh S1. Soal no 1 yang dikerjakan oleh S1 adalah

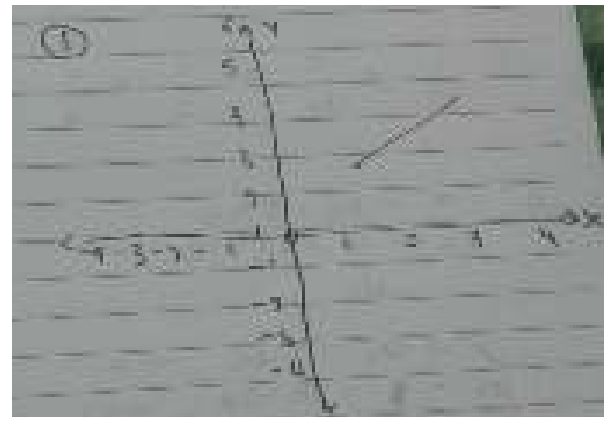

Gambar 8

Berdasarkan hasil S1 di atas, S1 melakukan kesalahan konsep karena S1 tidak memahami konsep matematika yang menjadi prasyarat untuk menyelesaikan soal. Kesalahan prinsip karena S1 keliru dalam mengaitkan konsep dalam menyelesaikan soal. Sedangkan untuk soal no 2 adalah

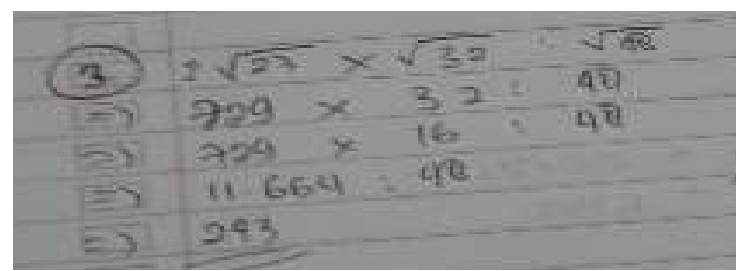

Gambar 9

S1 melakukan kesalahan konsep karena S1 tidak mengerjakan dengan benar sesuai dengan prasyarat penyelesaian aljabar. Kesalahan kecerobohan karena S1 melakukan kesalahan dalam perhitungan. Soal nomor 4 adalah

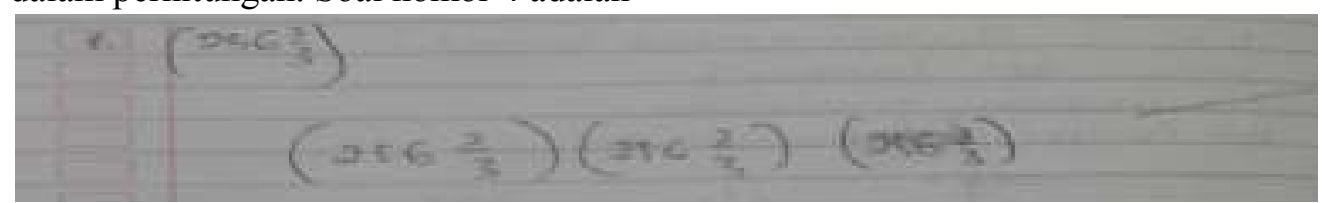

Gambar 10 


\section{Range: Jurnal Pendidikan Matematika Vol 1 No 1 Tahun 201S Hendrika Bete}

S1 melakukan kesalahan kecerobohan karena salah menulis soal yang mengakibatkan kesalahan konsep. S1 melakukan kesalahan konsep karena penyelesaiannya tidak sesuai syarat untuk menyelesaikan perpangkatan. Sedangkan soal nomor 6 adalah

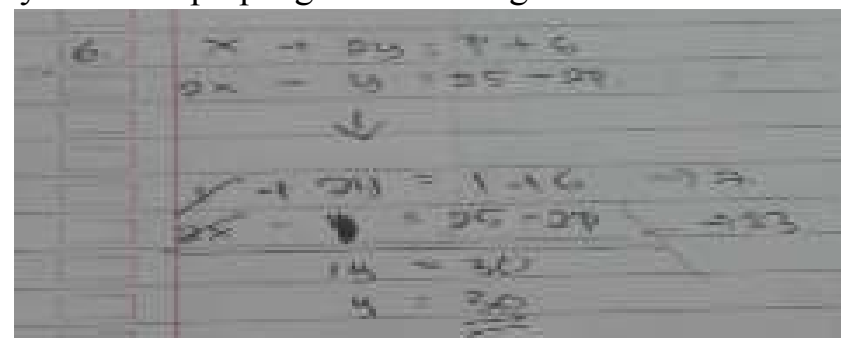

\section{Gambar 11}

S1 melakukan kesalahan konsep, kesalahan prinsip dan kesalahan kecerobohan.

b. Analisis kesalahan siswa berkemampuan sedang (S2) dalam menyelesaikan soal HOT pada materi aljabar

Analisis kesalahan siswa berkemampuan sedang (S2) dalam menyelesaikan soal HOT. S2 menyelesaikan soal - soal seperti yang diselesaikan S1. Kesalahan yang dilakukan adalah kesalahan kecerobohan yakni selain kesalahan dalam berhitung dan kesalahan, kecerobohan lainnya adalah jawaban S2 sama seperti jawaban S1 yang artinya tidak ada kejujuran dalam menyelesaikan soal. Salah satu contoh soalnnya adalah

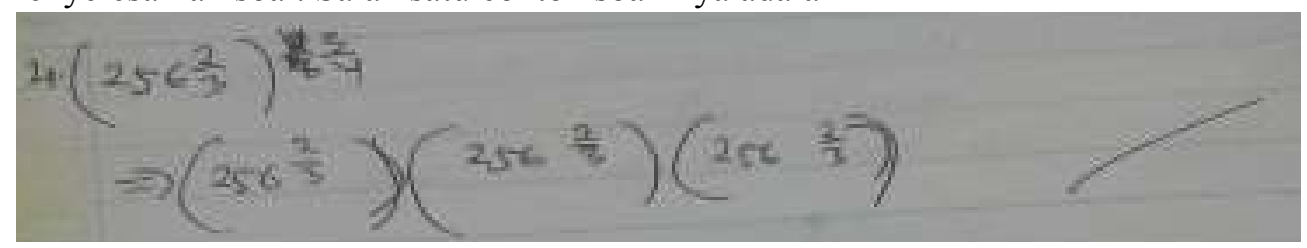

\section{Gambar 12}

c. Analisis kesalahan siswa berkemampuan rendah (S3) dalam menyelesaikan soal HOT pada materi aljabar

Analisis kesalahan siswa berkemampuan rendah (S3) dalam menyelesaikan soal HOT pada materi aljabar adalah dari 6 soal yang diberikan peneliti, S3 hanya menyelesaikan 2 soal. S3 pada soal no 1 hanya menggambarkan diagram cartesius, S3 melakukan kesalahan konsep karena S3 tidak memahami maksud soal, sehingga S3 salah

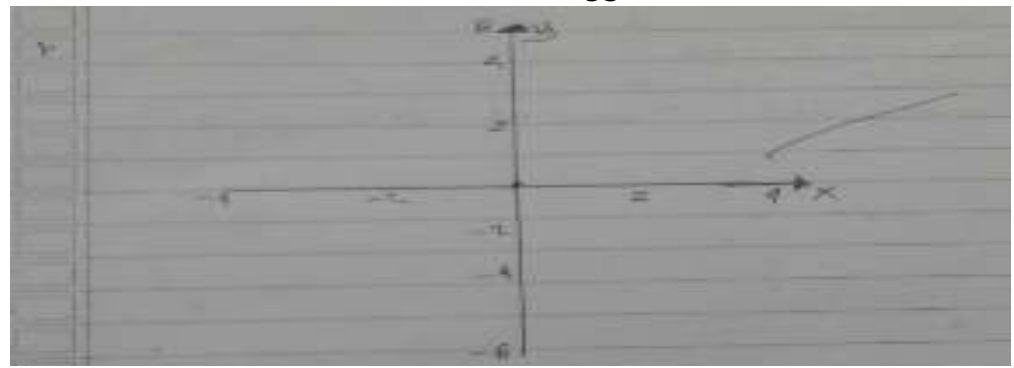

Gambar 13

Sedangkan soal no 2 yang diselesaikan oleh S3

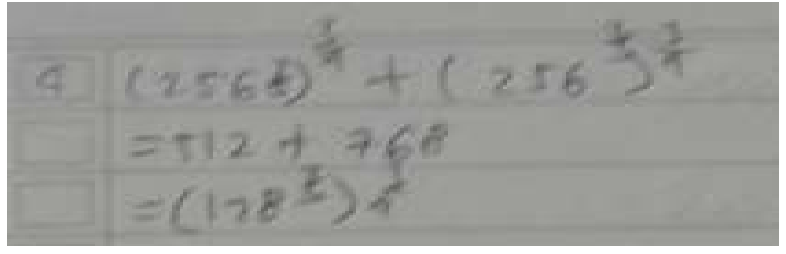

\section{Gambar 14}

S3 melakukan kesalahan konsep, karena penyelesaiannya tidak sesuai dengan persyaratan dan langkah - langkah yang sesuai dengan aljabar. S3 juga melakukan kesalahan prinsip yakni keliru dalam melakukan operasi perpangkatan pada bentuk aljabar. Serta kesalahan kecerobohan karena S3 melakukan kesalahan dalam menghitung. 


\section{Analisis Kesalahan Siswa SMP N Eban dalam Menyelesaikan Soal pada Materi Aljabar}

a. Analisis kesalahan siswa berkemampuan tinggi (S1) dalam menyelesaikan soal HOT pada materi aljabar.

Analisis kesalahan siswa berkemampuan tinggi dalam menyelesaikan soal HOT pada materi aljabar adalah S1 menyelesaikan 3 soal dari 6 soal yang diberikan peneliti. Soal yang dikerjakan adalah soal nomor 3, 4 dan 6 . Soal nomor 3 yang dikerjakan oleh $\mathrm{S} 1$ adalah

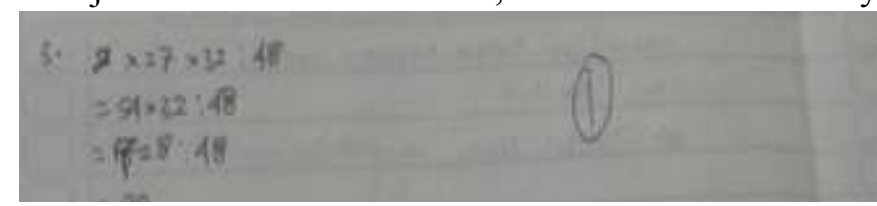

\section{Gambar 15}

Soal yang seharusnya diselesaikan dalam bentuk akar, S1 menyelesaikan dalam perkalian biasa. S1 melakukan kesalahan konsep dan kesalahan kecerobohan. Sedangkan soal no 4 yang diselesaikan oleh $\mathrm{S} 1$ adalah

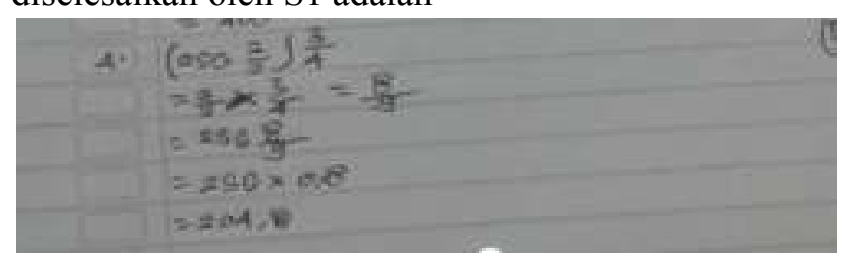

\section{Gambar 16}

Soal no 4 yang diselesaikan oleh S1 adalah S1 melakukan kesalahan konsep yakni S1 mengalikan pangkatnya saja, ini merupakan kesalahan konsep yang dilakukan oleh S1. Selain itu, S1 melakukan kesalahan kecerohan yakni S1 melakukan kesalahan dalam berhitung. Sedangkan soal no 6 yang diselesaikan oleh S1 adalah

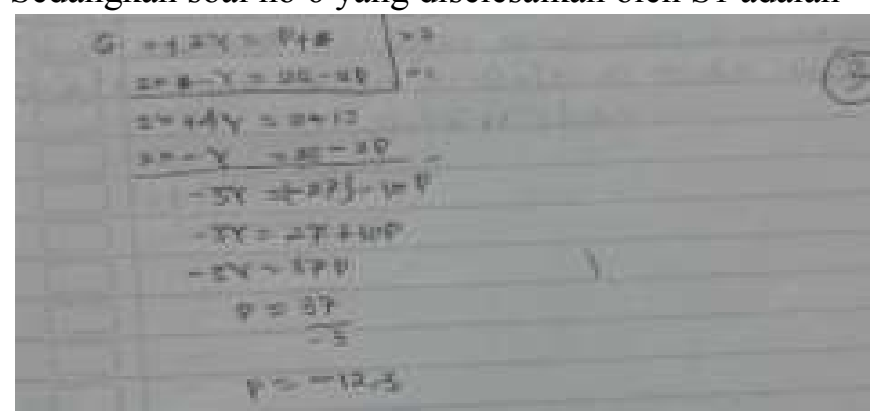

\section{Gambar 17}

Pada soal nomor 6, S1 melakukan kesalahan dalam menghitung, karena S1 menjumlahkan variabel dengan bilangan konstan sehingga S1 melakukan kesalahan kecerobohan.

b. Analisis kesalahan siswa berkemampuan sedang (S2) dalam menyelesaikan soal HOT pada materi aljabar

Kesalahan siswa berkemampuan sedang (S2) dalam menyelesaikan soal HOT pada materi aljabar adalah S2 menyelesaikan 3 soal dari 6 soal yang diberikan peneliti. Sedangkan 3 soal yang lain S2 hanya menulis soalnya saja. Dari 3 soal yang diselesaikan oleh S2, S2 menyelesaikan soal nomor 3, 4 dan 6 . Soal nomor 3 yang diselesaikan oleh S2 adalah

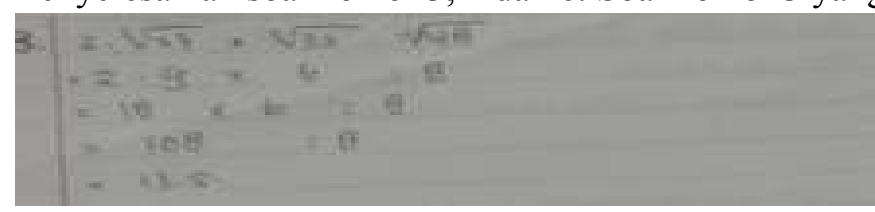

Gambar 18 
S2 melakukan kesalahan kecerobohan karena S2 melakukan kesalahan dalam berhitung, juga S2 melakukan kesalahan konsep karena S2 tidak memahami penyelesaian dari bentuk akar. Sedangkan soal nomor 4 yang diselesaikan oleh S2 adalah

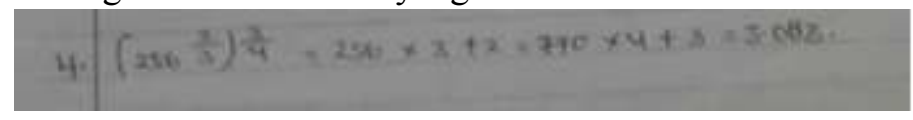

Gambar 19

S2 menyelesaikan soal dengan cara yang tidak sesuai dengan penyelesaian secara matematis, S2 keliru dalam menyelesaikan soal bentuk aljabar, S2 melakukan perkalian untuk bilangan pokok dan bilangan pangkat sehingga S2 melakukan kesalahan konsep dalam bentuk aljabar. sedangkan soal nomor 6 adalah

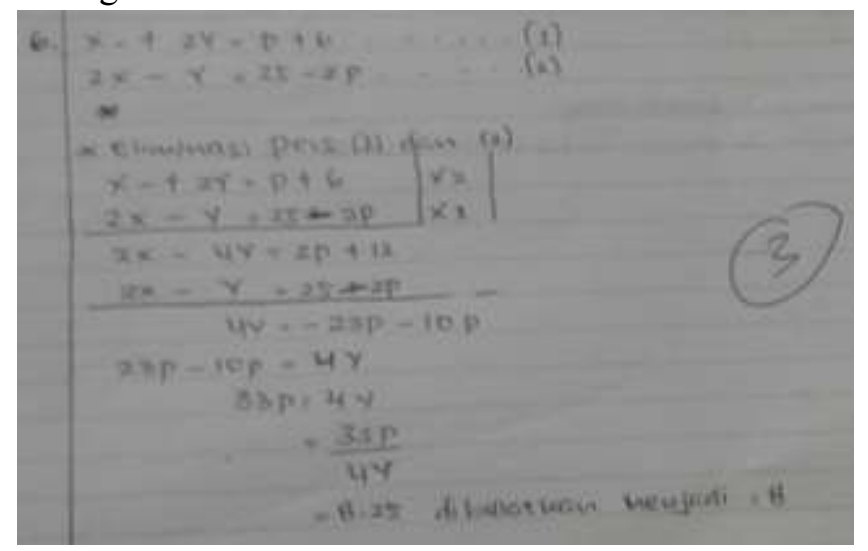

Gambar 20

S2 melakukan kesalahan konsep karena S2 membagi bilangan yang merupakan koefisien dari variabel yang berbeda. S2 salah dalam menyelesaikan soal dan melakukan kesalahan kecerobohan.

c. Analisis kesalahan siswa berkemampuan rendah (S3) dalam menyelesaikan soal HOT pada materi aljabar

S3 adalah siswa berkemampuan rendah, soal yang diberikan oleh peneliti sebanyak 6 soal. Dari 6 soal yang ada, S3 tidak dapat menyelesaikan semua soal, S3 hanya menulis soalnya saja sehingga peneliti tidak dapat melihat kesalahan yang dilakukan oleh S3.

\section{PEMBAHASAN}

Berdasarkan hasil tes dan hasil analisis peneliti tentang kesalahan siswa dalam menyelesaikan soal aljabar pada 9 subjek di atas, berikut ini akan dibahas beberapa hal yaitu siswa yang memiliki kemampuan tinggi lebih banyak menyelesaikan soal, tetapi siswa berkemampuan tinggi dari 3 sekolah melakukan kesalahan - kesalahan yakni kesalahan konsep, kesalahan prinsip dan kesalahan kecerobohan. Siswa menyelesaikan soal dengan tidak teliti juga tidak memahami materi sehingga mengakibatkan siswa melakukan kesalahan. Hal ini sejalan dengan penelitian Rosyidi (2015) bahwa, letak kesalahan antara lain salah dalam memahami soal, salah dalam pengerjaan soal, salah dalam memahami konsep. Dalam penelitian ini siswa banyak melakukan kesalahan konsep, karena soal yang diselesaikan oleh siswa tidak mengikuti persyaratan atau aturan yang seharusnya dalam menyelesaikan bentuk aljabar. selain itu, sebagian siswa tidak dapat menyelesaikan soal dan mengakibatkan salah dalam hasilnya karena tidak memahami kata - kata pada soal. Sama halnya dengan yang diungkapkan oleh Newman (1977), menyatakan bahwa sebagian besar siswa gagal matematika karena mereka tidak dapat membaca atau memahami kata - kata dari soal yang harus mereka selesaikan. Di pihak lain, penelitian ini juga dapat membantu guru dalam menangani siswa dalam menyelesaikan soal yang sering melakukan kesalahan. Hal ini dapat mengatasi siswa dalam melakukan kesalahan. Bray (2011), mengungkapkan bahwa, cara guru dalam menangani kesalahan siswa juga berpengaruh dalam mengatasi kesalahan yang dilakukan siswa. Cara guru dalam menangani kesalahan siswa dapat dipengaruhi oleh pengetahuan dan kepercayaan guru dalam 
mengajarkan matematika. Siswa kemampuan tinggi sedikit memahami penyelesaian menggunakan metode atau aturan penyelesaian materi aljabar berbentuk higher order thingking (HOT) tetapi banyak melakukan kesalahan. Kesalahannya adalah siswa dalam menyelesaikan soal tidak memperhatikan bentuk akar, siswa langsung mengalikan bilangan pokok tanpa menggunakan bentuk akarnya, kemudian pada soal perpangkatan siswa kemampuan tinggi hanya mengalikan bentuk pangkatnya saja. Selain itu siswa melakukan dalam penyelesaian soal yang seharusnya menyamakan penyebut siswa langsung menggantikan dengan bilangan yang lain. Sedangkan siswa dengan kemampuan sedang, tidak menyelesaikan semua soal, tetapi soal - soal yang diselesaikan juga terdapat banyak kesalahan yakni kesalahan konsep, kesalahan prinsip dan juga kesalahan kecerobohan. Siswa dengan kemampuan sedang juga menyelesaikan soal dengan tidak memperhatikan aturan dalam menyelesaikan soal aljabar. Siswa dengan kemampuan sedang menyelesaikan soal perpangkatan siswa mengalikan bilangan pokok dan bilangan pangkat, maka siswa kemampuan sedang melakukan kesalahan konsep. Selain itu siswa dengan kemampuan sedang menjumlahkan bilangan yang memiliki variabel berbeda sehingga siswa tersebut melakukan kesalahan kecerobohan. Sedangkan beberapa siswa dengan kemampuan rendah, kebanyakan tidak menyelesaikan soal tetapi menulis kembali soal yang diberikan peneliti, sehingga peneliti tidak dapat mendeskripsikan kesalahan yang dilakukan siswa. Adapun beberapa siswa lainnya dengan kemampuan rendah juga dalam menyelesaikan soal melakukan kesalahan yakni kesalahan konsep, kesalahan prinsip dan kesalahan kecerobohan. Siswa dengan kemampuan rendah menyelesaikan soal tidak memahami materi aljabar juga tidak menggunakan aturan atau prasyarat. Adapun kesalahan yang dilakukan siswa kemampuan rendah adalah siswa menjumlahkan aljabar yang seharusnya itu adalah materi perpangkatan.

\section{KESIMPULAN DAN SARAN}

Berdasarkan hasil penelitian dan pembahasan yang telah diuraikan sebelumnya maka dapat ditarik kesimpulan terhadap analisis kesalahan siswa dalam menyelesaikan soal berbentuk higher order thingking (HOT) pada materi aljabar.

Analisis kesalahan siswa dalam menyelesaikan soal berbentuk higher order thingking (HOT) adalah siswa dengan kemampuan tinggi menyelesaikan semua soal HOT, sedikit memahami bentuk aljabar tetapi dalam menyelesaikan soal banyak melakukan kesalahan. Siswa dengan kemampuan sedang menyelesaikan sebagian soal yang diberikan peneliti berbentuk higher order thingking tetapi tidak memperhatikan aturan atau prasyarat. Siswa dengan kemampuan sedang lebih banyak melakukan kesalahan konsep. Siswa dengan kemampuan rendah menyelesaikan hanya beberapa soal tetapi soal yang dikerjakan lebih banyak melakukan kecerobohan dan mengakibatkan kesalahan dalam menyelesaikan soal juga banyak kesalahan konsep. Siswa dengan kemampuan rendah sebagian tidak menyelesaikan soal, sebagian menyelesaikan soal tetapi tidak memahami aturan atau prasyarat pada materi aljabar.

Saran dalam peneltian ini adalah bagi peneliti lain agar lebih melihat tidak hanya materi aljabar tetapi untuk semua materi dalam pembelajaran matematika.

\section{DAFTAR PUSTAKA}

Bray, W.S. 2011. A Collective Case Study of The Influence Of Teachers' Beliefs And Knowledge On Error-Handling Prcatices During Class Discussion Of Mathematics. Jurnal For Research In Mathematics Education, 42 (1), 2 -38

Creswell, J. W.. 2012. Educational Research: Planning, Conducting, and Evaluating Quantitative and Qualitative Research. Lincoln: Pearson

Newman, A. 1977. "How To Solve it 2nd ed.New”. Tersedia: http://numeracyskills.com.au/newmans-analysis, diakses 10 Juni 2019 
Nurianti, Evi.dkk. Analisis Kesalahan Siswa dalam Menyelesaikan Soal Matematika Materi Pecahan Bentuk Aljabar Di Kelas VIII SMP. Pontianak: FKIP Untan

Poerwadarminta, W.J.S. 2006. Kamus Umum Bahasa Indonesia. Jakarta: Balai Pustaka

Riyanto, Yatim. 2007. Metodologi Penelitian Pendidikan Kualitatf dan Kuantitatif. Surabaya: Unesa University Press.

Rosyidi, Abdul Haris. 2015. Analisis Kesalahan Siswa Kelas II MTs Al-Khoiriyah dalam Menyelesaikan Soal Cerita yang Berkaitan SPLDV. Surabaya: Tesis UNESA, hal 19 